encroaching on the coast. The low water line has crept landward, and the beach has become more steep. There has also been a wasting a way of the foot of the sand dunes.

For the first part of the period over which the observations extend $\left(1843^{-56}\right)$, there appears to have been a retreat of the low water line from the shore, and consequent increase in width of the beach, in the northern portion of the coast for the first forty-four miles, and this continued up to 1866 to a less extent. After this, the low water line began to advance landwards until 1877 , when the northern beach began again to grow wider, but the decrease continued along the southern half. On an average there bas been a loss of beach along the whole coast between 1846 and 1894 , the total average loss for the forty-six years being 155 feet for North Holland and 108 feet for South Holland. The greatest change has taken place between the Helder and Petten, a distance of 12 miles, the low water line having advanced landward an average of I6o feet. Near Callangstoog, where the effect of the great gale of 1894 was most felt, the low water line is from 200 to 270 feet more inland than in 1846 , and the foot of the dunes has been driven back more than 300 feet.

Near Zandvoort there has been a gain of Ioo to I 30 feet. Near Scheveningen the low water line has approached nearer the shore, for a length of about four miles for about 200 feet, and the foot of the dunes has been scoured away to an average of roo feet, and in one place as much as 400 feet. The dunes have also wasted, although in a less degree. From the Helder to Egmont, a distance of 25 miles, there has been an average loss of about i 50 feet. From there to Ymuiden the foot of the dunes has remained about stationary; and from Ymuiden to the Hook of Holland, excluding the part at Scheveningen, there has been an average gain of about 65 feet.

Ymuiden Harbour is situated nearly in the centre of the embayment, and the piers project about a mile out from the shore. The works were commenced in 1865 , and finished in 1876 . Since the commencement of the piers, sand has accumulated both on the north and south sides of the harbour, and in I894 the accumulation had extended along the north pier seaward for a distance of about 1500 feet, and along the beach for $I_{2} \frac{1}{2}$ miles, this being the measure of the two sides of the triangle forming the pocket where the material had collected.

On the south side of the harbour the seaward measurement of the accumulation was at the same period 360 feet, and along the beach about $I_{4}^{1}$ miles.

The material thus accumulated appears to be due to a transposition of material, as previous to the piers the beach was increasing at this part of the coast, and has since considerably diminished.

The accumulation at the piers, forming the entrance to the Maas, which extend seaward about a mile, has not been so great. On the north side the sand has extended seaward, since the construction of the piers in $1863-72,820$ feet, the width of the extension along the beach being 2 miles. On the south side the accumulation extends outwards 700 feet. Here also there is a corresponding diminution of the beach for some distance to the north of the piers.

In December I 894 there occurred a very heavy gale, accompanied by the highest tide on the Dutch coast recorded during the present century, and an immense amount of damage was done to the fishing fleet. Out of 200 boats moored at the foot of the sand hills near Scheveningen, not one escaped without injury, and many were entirely destroyed. The damage done to the sand dunes, on which this part of the country depends for its protection from the sea, was very extensive, and throughout nearly the whole length the foot was washed away, leaving the mounds with steep sides. The stone pitching on the Helder Sea Dyke was damaged over a surface of about 5000 square yards. In North Holland, the tide broke through the sand hills in several places, and near Callanstoog the hills were breached for a distance of 2 miles, the tide inundating the low land behind.

W. H. WHEELER.

\section{RESULTS OF THE SCIENTIFIC EXPEDITION TO SOKOTRA.}

DURING the past winter a biological and geographical investigation of the Island of Sokotra (lying in about $12^{\circ}$ north latitude and $54^{\circ}$ east longitude), some 600 miles south-east of Aden, was undertaken, on behalf of the British Museum, by Mr. W. R. Ogilvie-Grant, and, on behalf of the Liverpool Cor- poration, by the Director of Museums (Dr. H. O. Forbes). Mr. W. Cutmore, of the Liverpool Museum, accompanied the party as taxidermist. From the Bulletin of the Liverpool Museums we learn that the expedition landed at Aden on November 18, 1898. Political difficulties between the Government of India and the Sultan of Sokotra unfortunately caused some delay in starting, but through the kindness of the Political Resident. Brigadier-General Creagh, V.C., these days were employed in visiting Sheik Othman and Lahej in South Arabia, where collections of considerable interest were made. On December $\mathrm{x}$, the difficulties referred to having been surmounted, the party was enabled to leave for Sokotra on board the Royal Indian Marine steamer Elphinstone, which had most generously been placed at its disposal by the Indian Government. Permission was also kindly given to detain the vessel for some days at Abd-el-Kuri, a previously unexplored island lying between Sokotra and Cape Guardafui, the eastern horn of Africa. There four days were spent in making as complete a collection of the fauna, flora and geology of the island as the time permitted. On December 7 , the expedition was landed on Sokotra, near Hadibu, the capital, and it remained on the island till February 22,1899 . On the return voyage, a second visit was paid to Abd.el-Kuri for a couple of days, to enable more complete collections from that out-of-the-way spot to be made.

A complete account of Sokotra, with a map, a list of the collections, and full descriptions of the new species obtained by the expedition, illustrated by plates and blocks, will be published as a special volume, which is now in active preparation. Meanwhile, short diagnoses of some of the more conspicuous zoological novelties are given in the May number of the Bulletin of the Liverpool Museums.

Dr. Forbes reports to the Museums Sub-Committee that the share which Liverpool receives of the collections is as follows :- Of mammals, there are examples of one or two species of rat, of one species of civet cat, of one species of bat, and of the wild ass. Of birds, there are some 300 specimens, $25^{\circ}$ in skin and 50 in spirit, out of which seven species have been diagnosed as new to science; a large series of reptiles has been acquired, which contains one genus and eight species new to herpetology. Numerous scorpions, millipedes and spiders, their exact number not yet ascertained, have been obtained, among which there turn out to be at least one new genus and seven new species; the land-shells number several thousands, of which Mr. Edgar Smith, of the British Museum, has already described eight species as new to his department of zoology. No doubt others will prove to be previously unknown. Of insects-almost the whole of which were collected by Mr. Ogilvie-Grant-there are several thousands, the majority of which have not yet been examined.

The plants, of which living specimens or ripe seeds-over 200 in number--have been brought home, are not only of the highest scientific interest, but, being at this moment unique out of Sokotra, are of great commercial value. Their cultivation is being undertaken by Prof. Bayley Balfour in the Royal Botanical Gardens, in Edinburgh. The plants, when in a condition to exhibit, will attract the keenest interest of all horticulturists by the beauty of many of them and by the bizarre form of others.

The report states that the true Sokoterians are only poorly civilised Mohamedans, living in caves or rude cyclopean huts, and possess but few utensils, implements, or ornaments, and no weapons. The ethnographical collection is consequently very small. Specimens of their pottery, of their primitive quern-like mills, of their basket work, and of their weaving apparatus were, however, obtained, and also two large blocks of stone, inscribed with an ancient script, which may perhaps throw some light on the indigenes of the island in a past age, and of whose cyclopean remains photographs were obtained.

Dr. Forbes concludes his report by pointing out that among scientific circles, especially among geographers and biologists, there has everywhere been expressed the warmest appreciation of the liberality and public-spirited action of the Liverpool Museums Committee and the City Council in taking part in the exploration of Sokotra; and also a hearty recognition of the great credit which unquestionably belongs to them of having been the first non-metropolitan Committee to recognise that it was the part of a great Corporation possessing an important scientific institution like the Liverpool Museums, not only to furnish their galleries with examples of what is already known, but also to further the advancement and increase of knowledge by actively sharing in the investigation of unknown regions. 